\title{
Improving Students' Reading Comprehension Through Listen-Read-Discuss (LRD) Strategy
}

\author{
Tawali \\ English Language Education, Faculty of Culture, Management, and Business \\ Mandalika University of Education \\ Corresponding Author. Email: tawaliyosi@gmail.com
}

\begin{abstract}
This research aimed at finding out whether Listen-Read-Discuss (LRD) strategy improves students' reading comprehension or not. The research was a classroom action research. The data collected through quantitative and qualitative approach. Quantitative data was gained from the result of pre-test and post-test from reading test. Meanwhile, qualitative data was gained from the result of observation sheets toward students' and teachers' activity. The instruments used by the researcher were test and observation sheet. The finding of the research showed that the strategy Listen-Read-Discuss improve the students' reading comprehension in descriptive text. The improvement can be seen from the mean score of students from pre-test, post-test one, and post-test two. The mean score of pre-tests was $64.46(50 \%)$, there were eight students who passed the minimum passing grade, in the post-test one, $75.35(67 \%)$, twelve students passed the minimum passing grade and in the post-test two, $82.14(89 \%)$, twenty-five students passed the minimum passing grade (KKM).
\end{abstract}

\section{Article History}

Received: $12-05-2021$

Revised: 19-06-2021

Accepted: 20-06-2021

Published: 07-07-2021

\section{Key Words:}

Listen-Read-Discuss,

Reading Comprehension.

How to Cite: Tawali, T. (2021). Improving Students' Reading Comprehension Through Listen-Read-Discuss (LRD) Strategy. Jurnal Paedagogy, 8(3), 322-327. doi:https://doi.org/10.33394/jp.v8i3.3852

\section{Introduction}

Reading is one of the skills which is essential for students to learn. Brown (2004) revealed that reading is also likewise a skill that teachers simply expect learners to acquire. By reading, the readers can increase their understanding about the text or what they have read, enrich their vocabularies and knowledge. Reading is a process which is done by a reader to get a message to delivered by the writer by words media or written language. Reading is complex skill which is complicated that covers or involves smaller series, Tarigan, (1996). It means that reading is the process to understand about the content of the text. Moreover, Chelsea (2001), Kamarudin (2016), Permana et al (2019), and Wahyuningsih (2021) revealed that reading comprehension is perhaps the most important set of skills you'll need to succeed.

Chelsea, (2001) defined that reading in a foreign language probably depends on your own previous language learning experience. Reading arguably the most essential skill for success in all educational contexts, remains a skill of paramount importance as we create assessment of general language ability. Reading is understanding a written text, a behavior, using word attack skill in identifying sound /symbol correspondences; using grammatical knowledge to recover meaning, using different technique for different purpose efficiently as possible (Grellet, 1999; Dallman. 1982; Nunan, 2003). There are two processes of reading called a sensory and a perceptual process. Firstly, reading begins as the sensory process in which the eyes bring stimuli to the reader. Second, the perceptual process that the reading is more than simply recognizing the printed words yet; it is a perceptual, conceptual and thinking process. And reading is commonly referred to as process, but when you study what happens when people learn to read you quickly discover that reading involves many 
processes simultaneously. (Dechant, 1982; Howard, 1980). Brown (2004) classified types of reading performance. They are; Perceptive, Selective, Interactive, and Extensive. Brown (2004) reveals that there are some indicators of reading comprehension, they are; Main idea, Vocabulary, Specific fact or detail, Exception, Location of information, and Inferences, and References.

After conducting the observation at SMPN 2 Lingsar, many students had problem and felt difficult at comprehending some reading texts because the content of the reading was initially covered orally, especially their lack vocabularies, structure and the process of understanding the ideas in the text, so, students were unable to read the entire text thoroughly. Thus, this research was done due to such reasons. The problems were also may be caused by several factors such as background knowledge, interest, attitude and the teacher. It is already known that the suitable technique and strategies can help both teacher and learners in teaching process. Hence, in this case, the researcher used LRD (Listen Read Discuss) strategy to teach reading comprehension to solve such problems. Some problems found within the observation and interview process were difficult at finding the main idea, detail implicit and explicit of information, reference, and meaning of words in the text; difficult at determining the referent of pronoun.

LRD is a comprehension strategy that builds students' prior knowledge before they read a text, during reading and after reading by listening the teacher's short lecture, reading a text selection, and discussing to increase their science inquiry strategies, comprehension rather than reading alone (Manzo and Rasinki, 2008; Burns, 2010; McKenna, 2002). Manzo \& Rasinki (2008) revealed some steps to do LRD; Listen, Read, and Discuss. Here are some procedures of conducting LRD, Manzo \& Rasinki, (2008) as follows:

a) Pre-Activities; (1) Teacher greets the students; (2) Teacher gives brainstorming to students; (3) Teacher stimulates students' curiosity. Students predict what they will read; (4) Facilitating the task. Teacher informs the class that teacher will present presentation which will cover all details of the material, but they will need to read to discover what questions these detail answer.

b) Whilst Activities; (1) Teacher presents the information from the text in the customary lecture style; (2) Reading. Give the student's times to read the textbook version of the same material; (3) Teacher puts the students into teams and provides times for students to delve into a topic in greater depth; (4) Checking comprehension and facilitating comprehension.

c) Post Activities; Practicing reading skill. (2) The teacher gives the score and does reflection. (2) The teacher closes the meeting.

This research aimed at finding out whether Listen-Read-Discuss (LRD) strategy improves students' reading comprehension or not.

\section{Research Method}

Classroom Action Research is a type of research in which its persistence is to construe event and allow people or group of people to frame acceptable solutions to local problems, to pursues feasible, maintainable, effective solutions to common problems, interpret phenomenon to adapt practice, and recognizes and addresses local problems with little regard for generalibility (Ary, et al, 2010). In this study, the researcher uses action research spiral proposed by Kemmis and McTaggart (2007) which consist of four stages (planning, acting, observing, and reflecting). 


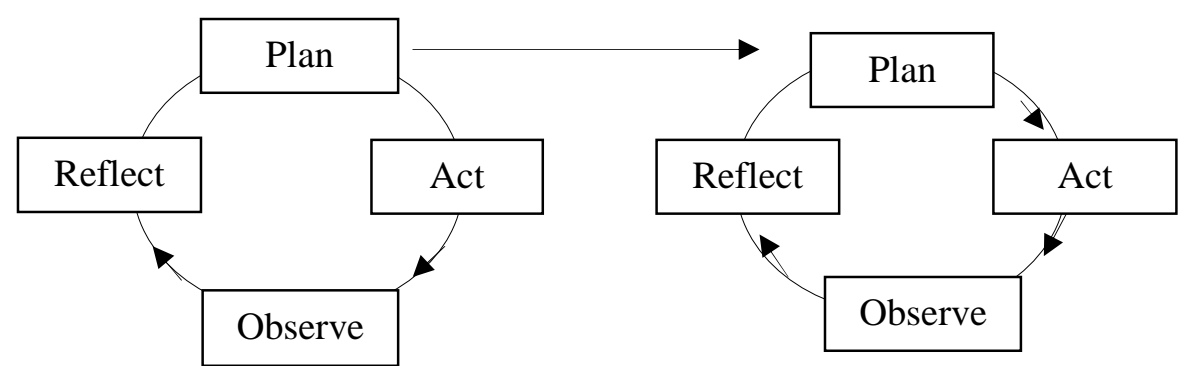

Figure 1. Classroom Action Research Design

This research was conducted within four stages, they are planning, acting, observing, and reflecting.

1) Planning; In this phase, the researcher prepared some preparations before implementing. Those preparations are: (a) The teaching material which relates to the syllabus and teaching media. (b) Lesson plan in order the teaching process is structured and run well. (c) Note of observation sheets to observe the classroom situation includes the students' behavior within the application of the method. (d) The classroom equipment such as the students' attendance list. (e) Criteria of success which is aimed to know the criteria and qualification of the students to be known as enhanced.

2) Acting; The researcher used act as a teacher teaching and learning process.

3) Observation; The observation stage aimed to observe students' behaviors toward the technique during teaching and learning process and also their result of tests whether it was enhanced or not.

4) Reflect; In this activity, both researcher and collaborator analyze the students' progress in their behaviors and learning achievement whether their reading comprehension is enhanced or not.

The subject of this research is class VIII- 8 which consists of 28 students they were 13 student females, and 15 student males. The students in this class were low reading comprehension they couldn't understand the meaning of the text. Meanwhile, as the object of the research was students' reading comprehension applying LRD strategies. The instrument of this research used test was given to find out the students' achievement in reading. The test was in the form of multiple choices consisted which cover indicator of reading comprehensions. This part deals with techniques of collecting the data consisted of test and observation sheet. The test was consisted of pre-test and post. Pre-test was given before doing an action and post-test was given after doing an action. Pre-test was aimed to know the student's achievement toward English reading comprehention, and then post-test was aimed to know to the students' skill and ability in teaching and learning process of reading comprehention through LRD strategy. The observation sheet was taken by collaborator (the English teacher) by providing papers intended to note every single of action happened within the process of teaching and learning in the classroom in every meeting. The observer was sitting at the back of the class and sometimes at the front or the corner. This was done to ease the seeing at the students' progress.

To analyze the data, the researcher used quantitative and qualitative. Quantitative approach used to analyze the data which was obtain from the test statistically in order to find out the students' achievement score of both pre-test and post-test whether or not they have different achievement after doing the research. Moreover, to measure the students' score the researcher used the following absolute norm five scales. 


$$
\begin{aligned}
& \bar{X}=\frac{\sum f x}{n} \\
& \mathrm{X} \quad=\text { the mean } \\
& \sum \mathrm{X} \quad=\text { thesum all of the score } \\
& N \quad=\text { the number of scores }
\end{aligned}
$$

After analyzing the average students' test, the researcher then used Observation sheet to get the description about the teacher and students' activities during teaching and learning process, and to record any single events which happen in the classroom. The data found then described qualitatively in the form of words, and sentences.

\section{Finding and Discussion}

After conducting the research, it was found that the score in the cycle 2 was higher than the cycle 1 . Here is the table of the score presented.

Table 1. Students' Score Test Cycle 1 and Test Cycle 2

\begin{tabular}{|l|l|c|c|c|l|}
\hline No & \multicolumn{1}{|c|}{ Name } & Cycle 1 & Cycle 2 & Gain & \multicolumn{1}{|c|}{ Note } \\
\hline 1 & Adelia Surli Dewi & 80 & 85 & 5 & Increased \\
\hline 2 & Agus Hardiawan & 65 & 75 & 10 & Increased \\
\hline 3 & Arya Aswadi & 70 & 75 & 5 & Increased \\
\hline 4 & Aulia Salsabila & 75 & 80 & 5 & Increased \\
\hline 5 & Bambang Subigio & 55 & 70 & 15 & Increased \\
\hline 6 & Fathan AlGifari & 85 & 90 & 5 & Increased \\
\hline 7 & Hera Angina & 70 & 75 & 5 & Increased \\
\hline 8 & I Gede Wardana & 80 & 85 & 5 & Increased \\
\hline 9 & I Gusti Bagus Raditya W. & 80 & 85 & 5 & Increased \\
\hline 10 & I Ketut Sujana & 85 & 90 & 5 & Increased \\
\hline 11 & Intan Lestari & 80 & 85 & 5 & Increased \\
\hline 12 & Irjanu Fathuzzilal & 50 & 65 & 15 & Increased \\
\hline 13 & Leni Marlina & 80 & 85 & 5 & Increased \\
\hline 14 & Liza Lafizza & 80 & 85 & 5 & Increased \\
\hline 15 & M. Ilham Hisam Syaputra & 80 & 90 & 10 & Increased \\
\hline 16 & Maulinda Apriani & 85 & 90 & 5 & Increased \\
\hline 17 & Meysya Degita Florentina & 90 & 95 & 5 & Increased \\
\hline 18 & Moh. Irsyadullail & 90 & 95 & 5 & Increased \\
\hline 19 & Ni Made Chika Awatari S. & 75 & 80 & 5 & Increased \\
\hline 20 & Ni Nyoman Novi Yanti & 80 & 85 & 5 & Increased \\
\hline 21 & Ni WayanAyu V. U. & 90 & 95 & 5 & Increased \\
\hline 22 & Rifaldi Putra Arianto & 80 & 85 & 5 & Increased \\
\hline 23 & RifkiYuniar & 70 & 75 & 5 & Increased \\
\hline 24 & Rini Herliana & 80 & 85 & 5 & Increased \\
\hline 25 & Ristawan & 55 & 75 & 20 & Increased \\
\hline 26 & Tesa Fariska & 80 & 85 & 5 & Increased \\
\hline 27 & Umar Usman & 70 & 75 & 5 & Increased \\
\hline 28 & Zaidan Amru Zahwin & $\mathbf{7 5 . 3 5}$ & $\mathbf{8 2 . 1 4}$ & & \\
\hline & Mean score & & & & \\
\hline & & 50 & 10 & Increased \\
\hline
\end{tabular}


Based on the table above, the cycle 2 was higher than cycle 1 . Such score was higher since they got motivation, enjoy, pay attention and become actively involved in the learning and direct their energies to the learning task along teaching - learning process. The mean score of the test cycle 2 is 82.14 . This result is better than the result of pre-test and test cycle 1. The mean score of the pre-test is 64.46 while the test cycle 1 is 75.35 . The improvement from the test cycle 1 to the test cycle 2 was 6.79 .

In the beginning of cycle 1 , it was observed that the students were interested in joining the lesson, they did not get difficulties to adapt the method of learning using LRD strategy into classroom activity. The difficulty was they were unconfident to speak up in front of the class and when they practice of descriptive text using learning trough LRD strategy. In the other hand, when they were divided into groups, they had been cooperative enough working in groups.

However, the students learned better in cycle 2 . In the cycle 2 the students studied and comprehend the text individually to optimize their ability in English lesson especially in reading comprehension of descriptive text. Good activities in teaching learning process helped the students to do the task well and comprehend the text discussed better.

\section{Discussion}

Based on the findings of research, the Listen-Red-Discuss strategy could enhance students' reading ability in descriptive text. It was proven by students' mean score and the total percentage and the students learning activity that increased in every meeting during teaching and learning process. In conducting the teaching and learning process on the first cycle, the researcher found that several of students still seemed confused and difficult to read or find out the ideas and less pay attention to teacher's explanation. Moreover, the result of the students' mean score on the first cycle did not meet the criteria of success. Therefore, the researcher and the collaborator decided together to conduct the second cycle.

Then on cycle two, the activities in this cycle were done better than the cycle one. The students involved actively in learning process and paid attention to the teacher's explanation. They looked enthusiastic to do the tasks by using this strategy and they followed every instruction from their teacher. Through Listen - Read - Discuss strategy involved students work within a group and do the investigation directly toward the object that given by the teacher.

Based on the result of data analysis on cycle 1, it was found the students' highest score was 85 and the lowest score was 30. Generally, in the cycle 1, there were 19 students who passed the test beyond the criteria of success was 75 based on the school agreement. And the rest of them 9 students were failed on the test or still under the criteria of success. Meanwhile, on the cycle 2, the students' highest score was 95 and the lowest score was 60. In this case, the students' progress showed that the students who achieved the criteria of success increased from 14 students $(50 \%)$ on cycle 1 to 19 students $(89 \%)$ in cycle two. From the result of cycle 1 and the cycle 2, it was showed that the Listen - Red - Discuss strategy could enhance students' reading comprehension in descriptive text.

\section{Conclusion}

After conducting the research and analyzing the result of the research, the researcher found that teaching reading using LRD Strategy in descriptive text can improve the students' reading comprehension especially in class VIII-8 of SMP N 2 Lingsar. It is proved by result of the students' mean score pre-test and post-test I improve from 64.46 to 78.75. And it improves again in cycle II between pre-test I and pre-test II improve from 78.75 to 85.17. 
Besides the students more understand the indicators of reading: 1) the students can identify the main idea in paragraph. 2) The students can find detail information of the text. 3) The students can classify the implicit of the text. 4) The students can find antonym or synonym of the text. 5) The students can identify reference of the text.

\section{Suggestion}

It is suggested that teachers and students may apply LRD strategy effectively in learning and teaching process, especially learning reading comprehension particularly descriptive text at school.

\section{References}

Ary, D., Jacobs,L. C., Sorencen, C., \& Razavieh, A (2010). Introduction to Research in Education (8th ed.). Canda: Wadsworth Cengage learning.

Burns, Anne. (2010). Doing Action Research in English Language Teaching: A Guide for Practitioners. New York and London: Routledge Taylor \& Francis Group. Richards,

Chelsea, Elizabeth. (2001). 8TH Grade Reading Comprehension Success. United Stated: Learning Express.

Dechant. (1982). Improving the Teaching of Reading: third edition. USA: Prentice Hall.

Dallman. (1982). The Teaching of Reading. New York: CBS College Publishing

Grellet, F. 1999. Developing Reading Skill: a practical guide to reading comprehension exercise. Cambridge: Cambridge University Press

Howard, G. P. (1980). An Assessment of Decision Analysis. Operations Research 28, pp, 427

Kamarudin, K. (2016). The Use of Small Group Discussion in Teaching Reading Comprehension at SMAN 2 Mataram. Jurnal Kependidikan: Jurnal Hasil Penelitian dan Kajian Kepustakaan di Bidang Pendidikan, Pengajaran dan Pembelajaran, 2(2). doi:https://doi.org/10.33394/jk.v2i2.454

Kemmis, Stephen and Mc Taggart, Robbin. (2007). Participatory Action Research. Denzin \& Lincoln Strategies

Manzo \& Rasinki, T.V. (2008). Listen-Read-Discuss: A content reading heuristic. Journal of Reading, 28, 732-734

Mckenna, M.C. (2002). Help for struggling Readers: Strategies for Grade: 3-8. New York: The Guildford Press.

Nunan, David. (2003). Practical English Language Teaching. New York: McGraw Hill

Permana, D., Suadiyatno, T., \& Harmawati, S. (2019). Note-Taking Pairs Strategy Towards Students' Critical Thinking Ability In Reading Comprehension. Jurnal Kependidikan: Jurnal Hasil Penelitian dan Kajian Kepustakaan di Bidang Pendidikan, Pengajaran dan Pembelajaran, 5(2), 75-83. doi:https://doi.org/10.33394/jk.v5i2.1797

Wahyuningsih, L. (2021). Meningkatkan Kemampuan Reading Comprehension Siswa SMA Negeri 1 Kebomas Melalui Extensive Reading. Jurnal Paedagogy, 8(1), 112-116. doi:https://doi.org/10.33394/jp.v8i1.3325 